\title{
Nursing education on collaborative discharge planning and motivating patients to control for further care and management
}

\author{
Dewi Kusumaningsih'1, Muhammad Agustianda² \\ ${ }^{1}$ Faculty of Medicine, Nursing and Health Sciences Malahayati University, Bandar Lampung, Indonesia. \\ Email: dewikusumaningsih@gmail.com \\ 2Public Health Centre Bandar Lampung, Indonesia. Email: muhammadiyanda20@gmail.com
}

\begin{abstract}
Background: Nurse as a health worker had a role as educators. The role of nurse educators could be seen from 10 inpatients resulted there were 4 inpatients (40\%) stated that nurses did their roles accurately and 6 patients $(60 \%)$ stated that there were nurses didn't their roles properly. This condition could cause an increasing amount of patients who uncontrolled at Dr. A. Dadi Tjokrodipo Hospital Bandar Lampung.

Purpose: To know there was a correlation of nursing education on collaborative discharge planning and motivating patients to control for further care and management

Methods: This research was quantitative method. The design of this study was an analytical survey with a crosssectional. The samples used in this study were 136 people. Collecting data sampling used a consecutive sampling. The statistical test used a chi-square test.

Results: The roles of nurse educator which had not good categories were 73 respondents $(53.7 \%)$ and the roles of nurse educator which had good category were 63 respondents (46.3\%). Low control motivations were 69 respondents $(50.7 \%)$ and high control motivations were 67 respondents $(49.3 \%)$. The results of data analysis using the chi-square test showed $p$-value $=0.001$.

Conclusion: There was a correlation of the roles of the nurse educator in discharge planning with motivation of inpatients for control. It was expected that the results of this study could be used as material for consideration and input for the hospital to be able to know the importance of the role of nurse educators in discharge planning.
\end{abstract}

\section{Keywords: Nursing education; Discharge planning; Motivating; Patients; Control; Management}

\section{INTRODUCTION}

Nurses as health workers have a role as educators. As an educator, nurses help clients to know the health and nursing care procedures they need to take in recovering or maintaining the health (Kozier, Erb, Berman, \& Snyder, 2010). The role of the nurse educators in carrying out their roles by providing education is also a part of discharge planning. The role of educator is the role that is carried out by assisting the client in increasing the level of health knowledge, symptoms of the disease, even actions to be given, so that there is a change in behavior from the client after health education (Asmadi, 2008; Febriana, 2017).

Nurses as the spearhead of health care providers in hospitals are expected to be able to carry out the role of educators in providing education to patients to improve patient compliance for control. Patient compliance will have expected goals of the program provided by health workers smoothly (Masi, \& Silolonga, 2018). Patient adherence rates for controls in eight American states are still low, of the 542 rehospitalization patients as many as 136 patients $(25 \%)$ were patients who were compliant to perform controls after hospitalization and 406 patients $(75 \%)$ were not compliant to control. Patients who were not compliant to control had a rehospitalization rate that increased by the time which has rate of $15 \%$ to $29 \%$ (Nelson, Maruish, \& Axler, 2000; Rahmania, Sudrajat, \& Ibrahim, 2017). In 2012, patients who were compliant to control in all hospitals in the United States as much as 20\% of all patients who had undergone the treatment (Leventhal, Taliaferro, Wong, Hughes, \& Mun, 2012). 
The scope of nursing health education practices carried out by nurses in carrying out the role of educator is responsible for providing health promotion and prevention of diseases in the environment such as schools, homes, hospitals, and industries (Bastable, 2002; Suryadi, Wijaya, \& Ardhiana, 2013). Basically, anurse is a teacher and health agent regardless of the environment in which the nurse works (National League of Nursing Education, 1937; Suryadi, Wijaya, \& Ardhiana, 2013).

Discharge planning requires good and directed communication, thus the patient can understand and be useful when the patient is at home. Until now, the discharge planning carried out by nurses has not been optimal, nurses are still focusing on routine activities, which are only in the form of recontrol information (Nursalam, \& Efendi, 2008).

The other thing that must be known by the client (patient) before going home is information about the disease the patient suffered. The information includes the understanding of diseases, causes, problems and complications can occur as well as how to anticipate them, written information about home care and information about the source of services can be utilized for control, telephone service numbers, doctors and home visits if the client requires. By providing health education to patients and families can be useful to improve the health levels of patients. The impact that can occur when nurses do not provide good health education can cause length of stay days and increase the number of relapses of patients after being at home (Sumah, 2018).

The condition can cause patients and families have not been able to do the treatment independently and they are not compliant to control. This is consistent with the previous research that there was a significant correlation between the role of nurse educators in discharge planning and the level of compliance of inpatients for control (Suryadi, Wijaya, \& Ardhiana, 2013). The health education can affect patient satisfaction about nursing services with $p$-value $=0,0001$ (Yosafianti, \& Alfiyanti, 2010).
The results of a preliminary study conducted by researchers at Dr. A. Dadi Tjokrodipo Hospital Bandar Lampung by filling out a questionnaire containing 24 questions about discharge planning to 8 nurses and 10 patients in the inpatient ward. In 8 nurses were given the questionnaire, 3 nurses $(37.5 \%)$ had good discharge planning implementation and 5 nurses $(62.5 \%)$ had poor discharge planning implementation. While from 10 patients who were given questionnaires for discharge planning by nurses, 4 patients (40\%) stated that if nurses had carried out discharge planning well, 6 patients $(60 \%)$ stated that if nurses had carried out discharge planning but it was poor.

Based on the results of a comparative study at Bumi Waras Hospital and Dr. A. Dadi Tjokrodipo Bandar Lampung, related to the control of patients in internal, surgical and pediatric disease poly, with a total number of controls in 2018 had 780 people in Dr. A. Dadi Tjokrodipo hospital, and 599 at Bumi Waras Hospital, while the control details at Dr. A. Dadi Tjokrodipo hospital was based on internal medicine poly disease was 325 controls, surgical poly was 288 control, and pediatric poly was 167 control.

\section{RESEARCH METHODS}

The type of this study is a quantitative method and the design of this study uses the Analytic Survey design with cross sectional approach. This research was conducted in three inpatient wards at Dr. A. Dadi Tjokrodipo Hospital Bandar Lampung on May 2019. The population in this study was all inpatients with the sample of 136 respondents. The sampling technique used in this study was consecutive sampling. This study passed the ethical eligibility of the Malahayati University Health Research Ethics Commission on April 2019.

Measuring instruments used in this study were nurse educator role and motivating patients to control questionnaires with consisted of 19 questions (Likert scale) with range score of 19 to 95 , while nurse educator role questionnaire consists of 20 questions by Likert scale with the range score of 20 to 100 .

Dewi Kusumaningsih' Faculty of Medicine, Nursing and Health Sciences Malahayati University,

Bandar Lampung, Indonesia. Email: dewikusumaningsih@gmail.com

Muhammad Agustianda ${ }^{2}$ Public Health Centre Bandar Lampung, Indonesia. Email: muhammadiyanda20@gmail.com 
Malahayati International Journal of Nursing and Health Science, Volume 02, No.2, September 2019: 52-58

Nursing education on collaborative discharge planning and motivating patients to control for further care and management

\section{RESEARCH RESULTS}

Table 1. The Frequency Distribution of the Role of Nurse Educators in Discharge Planning

\begin{tabular}{ccc} 
& & $\mathbf{N}=136$ \\
\hline Role of Nurse Educators & Frequency (f) & Percentage (\%) \\
& & \\
\hline Poor & 73 & 53,7 \\
Good & 63 & 46,3 \\
Total & $\mathbf{1 3 6}$ & $\mathbf{1 0 0}$ \\
\hline
\end{tabular}

From the table 1. above, it can be known that from 136 respondents with the role of nurse educator in the poor category is 73 respondents $(53.7 \%)$ and the role of nurse educator in the good category is 63 respondents $(46.3 \%)$.

Table 2. Frequency Distribution of Motivation Patients for Control

$$
\mathrm{N}=136
$$

\begin{tabular}{ccc}
\hline Motivation Patients for Control & Frequency (f) & Percentage (\%) \\
\hline Low & 69 & 50,7 \\
High & 67 & 49,3 \\
Total & $\mathbf{1 3 6}$ & $\mathbf{1 0 0}$ \\
\hline
\end{tabular}

From the table 2. above, it can be known that from 136 respondents who have low control motivation are 69 respondents (50.7\%) and high control motivation are 67 respondents $(49.3 \%)$.

Table 3. The Correlation of The Nurse Educator's Role In Discharge Planning and Motivating Patients to Control

\begin{tabular}{|c|c|c|c|c|c|c|c|c|}
\hline \multirow{4}{*}{$\begin{array}{l}\text { Nurse } \\
\text { Educator's Role }\end{array}$} & & & & & & & & $N=136$ \\
\hline & \multicolumn{4}{|c|}{ Control Motivation } & \multirow{2}{*}{\multicolumn{2}{|c|}{ Total }} & \multirow{3}{*}{ p-Value } & \multirow{3}{*}{$\begin{array}{l}\text { OR } \\
\mathrm{Cl} 95 \%\end{array}$} \\
\hline & \multicolumn{2}{|c|}{ Low } & \multicolumn{2}{|c|}{ High } & & & & \\
\hline & $\mathrm{n}$ & $\%$ & $\mathrm{n}$ & $\%$ & N & $\%$ & & \\
\hline Poor & 54 & $39,7 \%$ & 19 & $14,0 \%$ & 73 & $53,7 \%$ & & 9,095 \\
\hline Good & 15 & $11,0 \%$ & 48 & $35,3 \%$ & 63 & $46,3 \%$ & 0.001 & $(4,166-$ \\
\hline Total & 69 & $50,7 \%$ & 67 & $49,3 \%$ & 136 & $100 \%$ & & $19,853)$ \\
\hline
\end{tabular}

From the table 3. above, it can be known that 136 respondents whose nurse educator role is poor as many as 73 respondents $(53.7 \%)$ with low control motivation as many as 54 respondents (39.7\%) and high control motivation as many as 19 respondents $(14.0 \%)$. While the nurse educator role whose is good as many as 63 respondents $(46.3 \%)$ with low control motivation as many as 15 respondents $(11.0 \%)$ and high control motivation as many as 48 respondents (35.3\%).
The results of data analysis using the chi square test obtained $p$-value $=0.001(a<0.05)$, means that there is a correlation of the role of nurse educator in discharge planning with motivation of inpatients for control, with an $\mathrm{OR}$ value $=9.095$, means that the role of the nurse educator in Discharge planning is poor, thus cause 9 times the risk of low patient control motivation.

Dewi Kusumaningsih' Faculty of Medicine, Nursing and Health Sciences Malahayati University, Bandar Lampung, Indonesia. Email: dewikusumaningsih@gmail.com

Muhammad Agustianda² Public Health Centre Bandar Lampung, Indonesia. Email: muhammadiyanda20@gmail.com 

for further care and management

\section{DISCUSSION \\ The Role of Nurse Educators in Discharge Planning}

From the table 1. above, it can known that from 136 respondents with the role of nurse educator the poor category is 73 respondents $(53.7 \%)$ and the role of nurse educator in the good category is 63 respondents $(46.3 \%)$. Nursing is a form of professional health service which has an integral part of health services based on nursing knowledge and strategies. The scope of nursing includes promotive health services (health promotion), preventive (preventive activities for an illness), and providing nursing care to people who do not have the ability to get basic needs (Febriana, 2017).

Nurses as educators carry out their role in providing knowledge, information, and skills training to patients, patient's families and community members in efforts to prevent disease and improve health (Susanto, 2012; Suryadi, Wijaya, \& Ardhiana, 2013). Nurses as educators have a role in educating and teaching individuals, families, groups, communities, and other health workers in accordance with their responsibilities. Nurses as educators try to provide education or health couching to clients (patients) with evaluations that can enhance learning (Wong, 2009; Suryadi, Wijaya, \& Ardhiana, 2013).

In line with previous research, most of the respondents received discharge planning services in the poor category was 65 respondents with percentage $(57.5 \%)$ and good category was 48 respondents $(42.5 \%)$ (Natasia, Andarini, \& Koeswo, 2015).

According to the researcher the role of nurses as educators was done by assisting clients in increasing the level of health knowledge, symptoms of disease and even actions given, thus there was a change in behavior from clients after health education. Respondents explained that in the delivery of discharge planning, nurses use good and straightforward communication thus they are received by respondents.

In this study there are 3 aspects which have not fulfilled the role of the nurse educator properly, in terms of the questionnaire that has been filled out by respondents, such as nurses explaining what the uses of control are, nurses explain whenever they have to exercise control, nurses provide personal contact for respondents to ask questions.

\section{Motivation Patients for Control}

From the table 2 above, it can be known that from 136 respondents who have low control motivation is 69 respondents $(50.7 \%)$ and high control motivation is 67 respondents (49.3\%). Motive or motivation comes from the Latin word "moreve" means that the encouragement from the inside of humans to act or behave, the notion of motivation is not separated from the word "need" or "want" (Notoatmodjo, 2014).

Respondents who have low control motivation are caused by the lack of nurses' delivery of the risk factors if they do not have control and their lack of knowledge about the disease. If a person has high internal or external impulses, both the encouragement to recover or to go home immediately, thus the health level to be achieved is also greater. Encouragement from inside of the body can be in the form of conscience and conviction to heal, while encouragement from the outside is the spirit and support of the closest parts such as family and relatives (Uno, 2016). Motivation is a condition where individuals are motivated to behave towards certain goals. Thus, if motivation is high then the level of readiness is also getting higher, and it can be contrary (Hafizurrachman, 2009).

Whereas respondents who have high control motivation are caused by factors supporting respondents to carry out controls that are running properly, such as high motivation to recover, good knowledge about illness, or high family support for respondent's recovery thus encourages patients to be able to exercise good control.

According to the researchers, determine the direction of action is the goals to be achieved. Thus motivation can provide direction and activities that must be done deal with the goal that have been formulated in advance. Selecting actions by determining what actions must be done in harmony in order to achieve the goal, by setting aside actions that are not beneficial for the purpose. The

Dewi Kusumaningsih' Faculty of Medicine, Nursing and Health Sciences Malahayati University,

Bandar Lampung, Indonesia. Email: dewikusumaningsih@gmail.com

Muhammad Agustianda ${ }^{2}$ Public Health Centre Bandar Lampung, Indonesia. Email: muhammadiyanda20@gmail.com 

for further care and management

choice of actions that have been determined or done will provide high confidence because it has made the selection process.

In this study there are three aspects that have not fulfilled the role of nurse educator properly in terms of the questionnaire that has been filled out by the respondent, those are the respondent exercising control because there is a complaint on him, the patient controls because it follows the advice of others, and the patient does not want to control if they are not guaranteed healing.

\section{The Nurse Educator's Role In Discharge Planning and Motivating Patients to Control}

From the table 3. above, it can be known that 136 respondents whose poor of nurse educator's role are 73 respondents $(53.7 \%)$ with low control motivation are 54 respondents (39.7\%) and high control motivation are 19 respondents (14.0\%). While a good of nurse educator's role has 63 respondents $(46.3 \%)$ with low control motivation is 15 respondents (11.0\%) and high control motivation is 48 respondents (35.3\%). The results of the data analysis using the chi square test obtained $p$-value $=0.001$, means that there is a correlation the role of nurse educator in discharge planning with motivation of inpatients for control, with an OR value of 9.095 , means the role of the nurse educator in discharge planning is poor then 9 times has risk to provide low patient control motivation.

The role of the educator is the role which is carried out by assisting the client in increasing the level of health knowledge, symptoms of the disease, even actions that will be given, thus there is a change in the behavior of the client after health education. Nurses as educators must have the ability to assess the strengths and consequences resulting from the provision of information and behavior desired by individuals (Asmadi, 2008; Febriana, 2017).

This is in line with the previous research, statistical test results obtained $p$-value of 0.001 $(<0.05)$, means that there is a correlation of the role of the nurse educator in discharge planning and the level of compliance of inpatients for control at the Lung Hospital in Jember Regency (Suryadi, Wijaya, \& Ardhiana, 2013).

According to the researchers, the role of nurses as educators is very important to be carried out as well as possible for improving the health status, maintaining and or healing patients in general and patient recovery. The better the nurses provide health education about discharge planning to patients, the motivation for control will be higher.

The poor of nurse educator's role, but the high control motivation caused by family encouragement and high education of the family and patients, so that even in delivering nurses about the disease is lacking, respondents seek information about the source of pain and appropriate treatment methods actively. This condition influences respondents having good motivation. While the poor of nurse educator's role with low control motivation, can be caused by the delivery of discharge planning by nurses which is not supported by media such as leaflets, so the delivery given by nurses is less accepted by respondents.

The role of nurse educator even with low control motivation can be caused by education. Education is a system of activities aimed at processing learning. This process is designed to produce specific learning. Nurses in carnying out the role of educator help patients to improve their health through the provision of knowledge related to nursing and medical actions received, thus patients or families can accept responsibility for the things they know. While the role of nurse educator even with high control motivation can be caused by good delivery by nurses, education carried by nurses, and nurse's experiences during having service can affect communication and skills when doing discharge planning and affect respondent's perceptions to have a control (Sullivan\& Garland, 2010).

\section{CONCLUSION}

Most of the roles of nurse educators in the poor category are 73 respondents (53.7\%). Most of the respondents' motivations with low category are 69 respondents $(50.7 \%)$. The results of data analysis using the chi square test obtained $p$-value $=0.001$

Dewi Kusumaningsih' Faculty of Medicine, Nursing and Health Sciences Malahayati University,

Bandar Lampung, Indonesia. Email: dewikusumaningsih@gmail.com

Muhammad Agustianda² Public Health Centre Bandar Lampung, Indonesia. Email: muhammadiyanda20@gmail.com 

for further care and management

means that there is a correlation of the role of nurse educator in discharge planning with motivation of inpatients for control.

\section{RECOMMENDATION}

It is expected that the results of this study can be used as material for consideration and input for hospitals to find out the important role of nurse educators in discharge planning, thus the patient's motivation to control can be achieved according to the expected target. As well as recommendations for nurses to be able to be better in explaining what the use of control is, whenever they have to get control, and nurses are expected to provide personal contact for respondents to ask questions, and explain to patients to get even though they are not given a guarantee of recovery by the hospital.

The researcher also suggests that on the next researcher is able to examine in depth the other sub-variables of the implementation of the role of nurse educator in carrying out discharge planning not only to this extent but in a wider scope, such as using a research design in the form of experiments and observations.

\section{REFERENCES}

Asmadi, N. (2008). Konsep dasar keperawatan. EGC.

Bastable, S. B. (2002). Nurse as educator: Principles of teaching and learning for nursing practice. Jones \& Bartlett Learning.

Febriana, D. V. (2017). Konsep Dasar Keperawatan.

Hafizurrachman, H. (2009). Health status, ability, and motivation infl uenced district hospital nurse performance. Medical Journal of Indonesia, 18(4), 283-89.

Kozier, B., Erb, G., Berman, A., \& Snyder, S. J. (2010). Fundamental Keperawatan Konsep, Proses, \& Praktik. Jakarta: EGC.
Leventhal, T., Taliaferro, J. P., Wong, K., Hughes, C., \& Mun, S. (2012). The patient-centered medical home and health information technology. Telemedicine and e-Health, 18(2), 145-149.

Masi, G. M., \& Silolonga, W. (2018). Hubungan peran perawat sebagai edukator dengan kepatuhan penatalaksanaan hipertensi di Puskesmas Tahuna Timur. Jurnal keperawatan, 6(1).

Natasia, N., Andarini, S., \& Koeswo, M. (2015). Hubungan antara faktor motivasi dan supervisi dengan kinerja perawat dalam pendokumentasian discharge planning di RSUD Gambiran Kota Kediri. Jurnal Aplikasi Manajemen, 12(4), 723-730.

Nelson, E. A., Maruish, M. E., \& Axler, J. L. (2000). Effects of discharge planning and compliance with outpatient appointments on readmission rates. Psychiatric services, 51(7), 885-889.

Notoatmodjo, S. (2014). IImu perilaku kesehatan. Jakarta: Rineka Cipta, 200, 26-35.

Notoatmodjo, S. (2018). Metodologi Penelitian Kesehatan Jakarta: Rineka Cipta.

Nursalam, N., \& Efendi, F. (2008). Pendidikan Dalam Keperawatan Education in Nursing.

Rahmania, F., Sudrajat, D. A., \& Ibrahim, M. (2017). Hubungan Peran Educator Perawat Dalam Pelaksanaan Discharge Planning Dengan Tingkat Kepatuhan Pasien Untuk Kontrol di Instalasi Rawat Jalan RSUP Dr. Hasan Sadikin Bandung (Doctoral dissertation).

Stewart, I. M. (1937). A curriculum guide for schools of nursing. National league of nursing education.

Sullivan, E. J., \& Garland, G. (2010). Practical leadership and management in nursing. Pearson Education.

Dewi Kusumaningsih' Faculty of Medicine, Nursing and Health Sciences Malahayati University,

Bandar Lampung, Indonesia. Email: dewikusumaningsih@gmail.com

Muhammad Agustianda² Public Health Centre Bandar Lampung, Indonesia. Email: muhammadiyanda20@gmail.com 
Malahayati International Journal of Nursing and Health Science, Volume 02, No.2, September 2019: 52-58

Nursing education on collaborative discharge planning and motivating patients to control for further care and management

Sumah, D. F. (2018). Hubungan pengetahuan perawat dengan pelaksanaan discharge planning di RSUD Dr. M. Haulussy Ambon.

Suryadi, R. F., Wijaya, D., \& Ardhiana, A. (2013). Hubungan peran educator perawat dalam discharge planning dengan tingkat kepatuhan pasien rawat inap untuk kontrol di Rumah Sakit Paru Kabupaten Jember. Skripsi. Jember: Universitas Jember.

Susanto, T. (2012). Buku Ajar Keperawatan Keluarga: Aplikasi Teori pada Praktik Asuhan Keperawatan Keluarga. Jakarta: Trans Info Media.
Uno, H. B. (2016). Teori Motivasi \& Pengukurannya. Cetakan keempat belas. PT. Bumi Aksara. Jakarta.

Wong, D. L. (2009). Buku ajar keperawatan pediatrik vol 1 wong. EGC.

Yosafianti, V., \& Alfiyanti, D. (2010). Pengaruh Pendidikan Kesehatan Persiapan Pasien Pulang Terhadap Kepuasan Pasien Tentang Pelayanan Keperawatan di RS Romani Semarang. In Prosiding Seminar Nasional \& Internasional (Vol. 1, No. 1).

Dewi Kusumaningsih' Faculty of Medicine, Nursing and Health Sciences Malahayati University, 